\title{
Dissociation of Proton-Bound Complexes and Proton Affinity of Benzamides
}

\author{
H.-F. Grützmacher and Anke Caltapanides \\ Lehrstuhl I für Organische Chemie, Fakultät für Chemie, Universität Bielefeld, P.O.B. 1001 31, D-33501 \\ Bielefeld, Germany
}

\begin{abstract}
Proton-bound heterodimers of substituted benzamides 1-15 and $N, N$-dimethyl benzamides 16-30, respectively, with a series of reference bases were generated under chemical ionization conditions. Their dissociation into the protonated amide $\mathrm{AH}^{+}$and protonated reference base $\mathrm{BH}^{+}$was studied by metastable ion techniques and by collision-induced dissociation (CID) to examine substituent effects on the proton affinity (PA) of the benzamides and to elucidate some aspects of the dissociation dynamics of proton-bound clusters. The PAs of the substituted benzamides were determined by bracketing the amide by a pair of reference bases to give rise to more and less abundant signals of the protonated base in the mass-analyzed ion kinetic energy (MIKE) spectra of the proton-bound heterodimers. The substituent effects observed agree with $\mathrm{O}$-protonation in both the primary and the tertiary benzamides. However, the susceptibility of the benzamide to polar substituent effects is remarkably small, which indicates a "resonance saturation" of the amide group. The relative abundances of $\mathrm{AH}^{+}$and $\mathrm{BH}^{+}$in the MIKE and collisional activation (CA) mass spectra depend strongly on the pressure of the collision gas during CID, and in certain cases a reversal of the relative abundances with increasing pressure that favors the formation of $\mathrm{BH}^{+}$from a less basic reference base is observed. Although this effect underlines the limited possibilities of the "kinetic method" for PA determination by CID of proton-bound heterodimers, it uncovers important kinetic effects during the dissociation of proton-bound heterodimers and of proton transfer reactions in the gas phase. In the case of the protonated amide clusters, the observed intensity effects in the $\mathrm{CA}$ mass spectra are explained by a double-well potential energy surface caused by solvation of the protonated base by the polar amide in the protonated heterodimer. (J Am Sac Mass Spectrom 1994, 5, 826-836)
\end{abstract}

$\mathrm{P}$ roton transfer between molecules is one of the important fundamental chemical processes. Proton transfer reactions and in particular acid-base equilibria in solution have been studied for a long time, and it is well known that these reactions are strongly influenced by solvent effects [1]. Therefore, the quantitative study of proton transfer reactions and equilibria in the gas phase is of special interest to separate intrinsic properties of the molecules from solvent effects [2]. In addition, most of the organic reactions take place in nompolar organic solvents with dielectric constants distinctly less than that of water, and even enzymatic processes of biochemistry and physiology proceed in a nonpolar environment more related to organic solvents than to water [3]. However, most acid-base equilibria have been studied in aqueous solution. Hence, gas-phase basicity (GB) and proton affinity (PA) of organic compounds are fundamental molecular properties that permit a profound insight into the correlations between molecular structures,

Address reprint requests to Dr. H.-F. Grützmacher, Lehrstubl I für Organische Chemie, Fakultät für Chemie der Universität Bielefeld, Postfach 100131 , D-33501 Bielefeld, Germany. molecular stability, and reactivity [4], and are at least as useful as data from aqueous solution for an extrapolation to properties of ions in organic environments.

An important phenomenon related to GB and PA is the formation of hydrogen bonds between molecules [5]. Hydrogen bonding in solution is not only important for solvent effects of polar solvents but also for the creation of supermolecular structures by association and for the formation of tertiary structures of proteins and related natural compounds. In this connection, a study of the formation and the dissociation of hydrogen-bound dimers and clusters in the gas phase is very informative. In view of the important phenomena linked to transfer and association of protons to protein molecules [6] with a backbone structure of peptide bonds, a study of the GBs and PAs of amides and of the properties of their gaseous proton-bound complexes is of special importance. The PAs of the common amino acids and of some simple peptides have been published recently [7], but the GBs and PAs of only a few amides have been determined so far [8]. However, a reliable knowledge of the GB and PA of a set of structurally related amides is necessary to obtain rules that allow extrapolations to structural effects on these quantities in complicated large biomolecules. 
Protonation of amides in acidic solutions occurs at the oxygen atom of the amide group [9]. However, the $\mathrm{N}$-protonated isomer is involved in hydrogen bonding of amides and in proton exchange reaction of amides in solution [10]. The location of the proton added in gaseous protonated amides has not been determined, but theoretical calculations show a preference for $\mathrm{O}$ protonation [11]. In spite of this, the small effect of the acyl group on the PAs of some tertiary amides [12] may be an indication of $\mathrm{N}$-protonation at least for tertiary amides in the gas phase. A possibility to distinguish between $\mathrm{O}$ - and $\mathrm{N}$-protonation of amides in the gas phase is a systematic study of substituent effects on the GBs and PAs of primary and tertiary benzamides. A polar substituent effect at the para position is linked by resonance to the positive charge of the amide group only in the case of an O-protonation and leads to different effects of the same substituents at the meta and the para positions. In the case of $\mathrm{N}$-protonation the substituted benzoyl group will exert only inductive effects on the ammonium group, and one would expect only small differences owing to the meta or para position of identical substituents. Therefore, in the case of a different location of the attached proton in these two series of benzamides, distinctly different substituent effects on the PA are expected. Here we report the substituent effects on the PAs of primary benzamides and tertiary N,N-dimethyl benzamides to test this concept.

The GBs of organic compounds are preferably derived from measurements of proton transfer equilibria to reference bases of known GB [2]. In these studies it is important to prove that thermal equilibrium of the transfer reaction is established rather than some other kind of steady state. This is particularly difficult if the equilibrating system is disturbed by side reactions. In the case of polar compounds the formation of protonbound dimers and clusters is a likely side reaction, especially under the conditions of high pressure mass spectrometry. Carboxamides are very polar and the extensive formation of proton-bound homodimers and heterodimers is observed even under the low pressure conditions of Fourier transform ion cyclotron resonance spectrometry [12]. Thus, correct measurements of proton transfer equilibria that involve amides are difficult. Cooks and co-workers [13] have suggested a convenient technique for the determination of the (relative) PAs of polar compounds based on the unimolecular dissociation of proton-bound complexes in a tandem mass spectrometer. Usually the only decomposition observed for a proton-bound heterodimer corresponds to the dissociation into the protonated components, and the relative rates of the two possible reaction paths can be related to the relative PAs of the components. Because proton-bound heterodimers of an amide with a variety of reference bases are generated easily in the ion source of a tandem mass spectrometer under the conditions of chemical ionization, this so-called kinetic method [13] appears
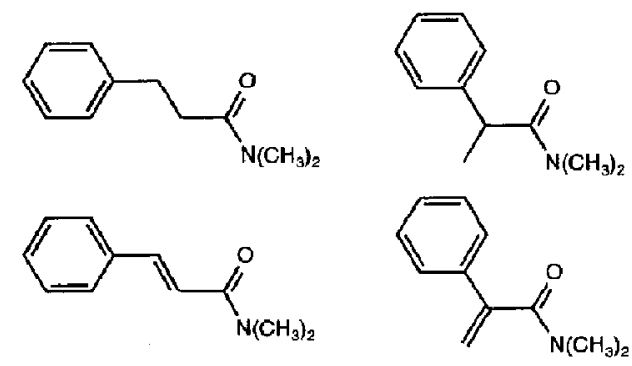

$\mathrm{PA}=929 \pm 2[\mathrm{~kJ} / \mathrm{mol}]$

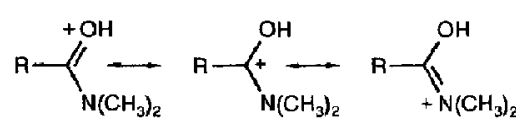

O-protonation (resonance structures)

Scheme I.

to be well suited for a determination of the PAs of amides.

In the original version of the "kinetic method" a linear correlation between the ratio of the intensities of the relevant ions formed from the proton-bound heterodimer and the PA difference of its components is assumed [13]. Hence, after calibrating this correlation with a few pairs of proton-bound heterodimers, the PAs are determined by interpolation from the corresponding calibration curve. Recently it was shown [7h, $7 i, 141$ that this correlation is not valid if the molecular geometry of the compounds studied changes on protonation. Here we will show that an interpolation generally is not valid for polar compounds because of certain effects in the dissociation dynamics of protonbound heterodimers. In fact, the kinetic method that uses the linear extrapolation can be used reliably only in a few special cases, as already mentioned by Cooks and co-workers [15]. Thus, the use of the technique to measure the dissociation of proton-bound clusters for a determination of PA should be restricted to the study of metastable clusters of low internal energy and to the use as a bracketing method.

\section{Experimental}

The primary benzamides 1-15 and the tertiary $N, N$ dimethyl benzamides 16-30 (Scheme II) were prepared from the corresponding substituted benzoyl chlorides by treatment with concentrated aqueous ammonia and a solution of dimethyl amine hydrochloride in $20 \%$ aqueous $\mathrm{NaOH}$, respectively, via standard procedures of organic chemistry [16]. The purity and structure of the amides were verified by thin-layer chromatography, ${ }^{1} \mathrm{H}$ nuclear magnetic resonance spectroscopy, and electron ionization (EI) mass spectrometry (70 eV). The reference bases used for this study are commercially available and were used without further purification. 


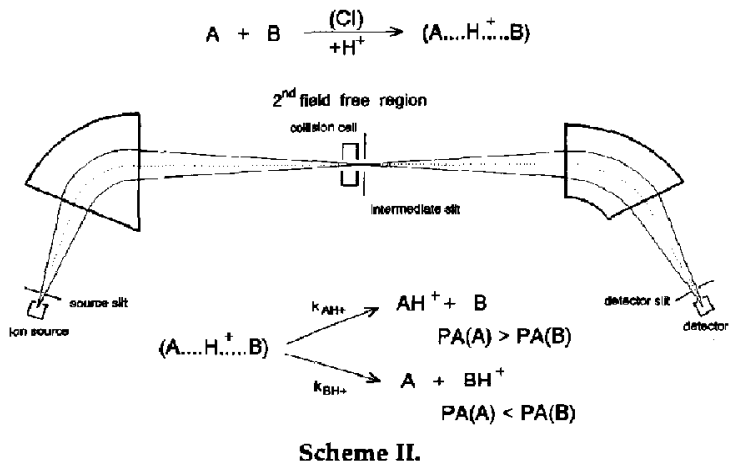

Mass spectrometric measurements were performed with a double-focusing mass spectrometer (Fisons VG Autospec, Fisons Instruments, VG Analytical, Manchester, UK) equipped with a chemical ionization (CI) ion source. Methane at an ion source pressure of $2 \times$ $10^{-4}$ mbar (measured with a Bayard-Alpert ion gauge before the ion source high vacuum pump) was used for chemical ionization at an ion source temperature of $160^{\circ} \mathrm{C}$, electron energy of $70 \mathrm{eV}$, electron emission current of $200 \mu \mathrm{A}$, and an accelerating voltage of $8 \mathrm{kV}$. Mixtures of the respective amide and a selected reference base (molar ratio 1:5) were admitted into the ion source until the total ion source pressure was $3-6 \times$ $10^{-4}$ mbar, and the proton-bound dimers were formed with sufficient intensity. The proton-bound heterodimer that contained the amide and the reference base was selected by setting the magnetic field strength to the appropriate mass-to-charge ratio value and focusing the selected ions into the last field-free region of the Autospec instrument. The fragmentations of metastable proton-bound clusters were followed by scanning the second electrostatic analyzer of the $\mathrm{Au}$ tospec mass spectrometer [mass-analyzed ion kinetic energy (MIKE) spectrometry]. Collision-activated (CA) mass spectra were obtained analogously but by the introduction of $\mathrm{He}$ into the collision cell of the field-free region behind the magnetic analyzer. The CA spectra were recorded at various He pressures in the collision cell ranging from $1-3 \times 10^{-6}$ mbar measured at the ion gauge before the analyzer high vacuum pump of the Autospec mass spectrometer.

\section{Results and Discussion}

\section{Substituent Effects on the Proton Affinity of Benzamides and $\mathrm{N}, \mathrm{N}-$ Dimethyl Benzamides}

The PAs of the benzamides 1-15, of the $N, N$-dimethyl benzamide 16-30 (Scheme III), and of the reference bases [8] used for the determination are listed in Tables 1 and 2. The PAs of the amides are derived from the unimolecular fragmentation of the respective proton-bound heterodimers generated in the ion source under CI conditions. The MIKE spectra of these pro-<smiles>[X]c1ccc(C(N)=O)cc1[X]</smiles>

\begin{tabular}{ll|ll}
$\mathrm{X}$ & $\mathrm{Y}$ & & \\
\hline $\mathrm{H}$ & $\mathrm{H}$ & $\mathbf{1}$ & \\
$\mathrm{H}$ & $\mathrm{NH}_{2}$ & 2 & 16 \\
$\mathrm{NH}_{2}$ & $\mathrm{H}$ & 3 & 17 \\
$\mathrm{H}$ & $\mathrm{OCH}_{3}$ & 4 & 18 \\
$\mathrm{OCH}_{3}$ & $\mathrm{H}$ & $\mathbf{5}$ & 19 \\
$\mathrm{H}$ & $\mathrm{CH}$ & 6 & 20 \\
$\mathrm{CH}_{3}$ & $\mathrm{H}$ & 7 & 21 \\
$\mathrm{H}$ & $\mathrm{F}$ & 8 & 22 \\
$\mathrm{~F}$ & $\mathrm{H}$ & 9 & 24 \\
$\mathrm{H}$ & $\mathrm{Cl}$ & 10 & 25 \\
$\mathrm{Cl}$ & $\mathrm{H}$ & 11 & 26 \\
$\mathrm{H}$ & $\mathrm{CF}$ & 12 & 27 \\
$\mathrm{CF}$ & $\mathrm{H}$ & 13 & 28 \\
$\mathrm{H}$ & $\mathrm{NO}_{2}$ & 14 & 30 \\
$\mathrm{NO}_{2}$ & $\mathrm{H}$ & 15 & \\
& & Scheme III. &
\end{tabular}

ton-bound heterodimers exhibit only signals for a fragmentation into the protonated components, that is, the protonated base and the protonated amide. Additionally, CA spectra were measured to ensure that the ions selected for analysis are indeed proton-bound pairs and not covalently bonded products of ion-molecule reactions induced by the collision of the protonated species with neutral molecules. This would be detected in the CA spectra by signals of ions composed of groups from both components of the cluster. The CA spectra of the proton-bound heterodimers from the amides and reference bases listed in Tables 1 and 2 exhibit intense signals only for the protonated components, and only at high pressures of the collision gas do additional small peaks of ions that result from further fragmentations of the protonated components appear. Thus there are no indications for covalent bonding in these clusters. However, as will be discussed in the next section, the intensity ratio of the signals of the protonated components in the MIKE and CA spectra change and depend distinctly on the pressure of the gas in the collision cell. Accordingly, it is not possible to determine the PAs of the amides by the usual interpolation technique of the kinetic method. Instead, the signals of the protonated amide and the protonated reference base were taken only from the MIKE spectra of the proton-bound heterodimers to bracket qualitatively the PA of the amide by a pair of reference bases, which give rise to less and to more abundant protonated base, respectively, compared with the protonated amide. The rationale for this PA determination is the assumption that the MIKE spectra show only the dissociation products of clusters of small internal energies, and that at least during the dissociation of a cluster with low excess energy the proton will stay preferentially with the more basic 
Table 1. Proton affinities (PA) of substituted benzamides 1-15 and of reference bases [8] used for bracketing

\begin{tabular}{|c|c|c|c|}
\hline Substituent & $\begin{array}{c}\text { PA } \\
(\mathrm{kJ} / \mathrm{mol})\end{array}$ & Bracketing bases & $\begin{array}{c}\text { PA } \\
\langle\mathrm{kJ} / \mathrm{mol}\rangle\end{array}$ \\
\hline $\begin{array}{l}H \\
1\end{array}$ & $887 \pm 7$ & $\begin{array}{l}N, N \text {-Dimethyl formamide } \\
o \text {-Phenylene diamine }\end{array}$ & $\begin{array}{l}884 \\
890\end{array}$ \\
\hline $\begin{array}{l}m-\mathrm{NH}_{2} \\
2\end{array}$ & $897 \pm 5$ & $\begin{array}{l}\text { 2-Aminophenol } \\
\text { 2-Bromopyridine }\end{array}$ & $\begin{array}{l}896 \\
898\end{array}$ \\
\hline $\begin{array}{l}p-\mathrm{NH}_{2} \\
3\end{array}$ & $923 \pm 5$ & $\begin{array}{l}\text { 2-Butyl amine } \\
\text { Pyridine }\end{array}$ & $\begin{array}{l}922 \\
924\end{array}$ \\
\hline $\begin{array}{l}m-\mathrm{OCH}_{3} \\
4\end{array}$ & $897 \pm 5$ & $\begin{array}{l}\text { 2-Aminophenol } \\
\text { 2-Bromopyridine }\end{array}$ & $\begin{array}{l}896 \\
898\end{array}$ \\
\hline $\begin{array}{l}p-\mathrm{OCH}_{3} \\
5\end{array}$ & $901 \pm 7$ & $\begin{array}{l}\text { 2-Bromopyridine } \\
\text { p-Phenylene diamine }\end{array}$ & $\begin{array}{l}898 \\
903\end{array}$ \\
\hline $\begin{array}{l}m-\mathrm{CH}_{3} \\
6\end{array}$ & $897 \pm 5$ & $\begin{array}{l}\text { 2-Aminophenol } \\
\text { 2-Bromopyridine }\end{array}$ & $\begin{array}{l}896 \\
898\end{array}$ \\
\hline $\begin{array}{l}p-\mathrm{CH}_{3} \\
7 \\
\end{array}$ & $897 \pm 5$ & $\begin{array}{l}\text { 2-Aminophenol } \\
\text { 2-Bromopyridine }\end{array}$ & $\begin{array}{l}896 \\
898\end{array}$ \\
\hline $\begin{array}{l}m-F \\
8\end{array}$ & $875=6$ & $\begin{array}{l}\text { 4-Chloroaniline } \\
\text { Aniline }\end{array}$ & $\begin{array}{l}873 \\
876\end{array}$ \\
\hline $\begin{array}{l}\rho-F \\
9 \\
\end{array}$ & $875 \pm 6$ & $\begin{array}{l}\text { 4-Chloroaniline } \\
\text { Aniline }\end{array}$ & $\begin{array}{l}873 \\
876\end{array}$ \\
\hline $\begin{array}{l}m-C l \\
10\end{array}$ & $875 \pm 6$ & $\begin{array}{l}\text { 4-Chloroaniline } \\
\text { Aniline }\end{array}$ & $\begin{array}{l}873 \\
876\end{array}$ \\
\hline $\begin{array}{l}p-\mathrm{Cl} \\
11\end{array}$ & $875 \pm 6$ & $\begin{array}{l}\text { 4-Chloroaniline } \\
\text { Aniline }\end{array}$ & $\begin{array}{l}873 \\
876\end{array}$ \\
\hline $\begin{array}{l}m-\mathrm{CF}_{3} \\
12\end{array}$ & $865 \pm 7$ & $\begin{array}{l}\text { Diisopropyl ether } \\
\text { Pyrrole }\end{array}$ & $\begin{array}{l}862 \\
868\end{array}$ \\
\hline $\begin{array}{l}\rho-\mathrm{CF}_{3} \\
13\end{array}$ & $864 \pm 6$ & $\begin{array}{l}\text { Diisopropyl ether } \\
\text { 3-Fluoroaniline }\end{array}$ & $\begin{array}{l}862 \\
866\end{array}$ \\
\hline $\begin{array}{l}m-\mathrm{NO}_{2} \\
14 \\
\end{array}$ & $857 \pm 9$ & $\begin{array}{l}\text { Di-n-butyl ether } \\
\text { Diisopropyl ether }\end{array}$ & $\begin{array}{l}852 \\
862 \\
\end{array}$ \\
\hline $\begin{array}{l}p-\mathrm{NO}_{2} \\
16\end{array}$ & $849 \pm 7$ & $\begin{array}{l}\text { Di-n-propyl ether } \\
\text { Di-n-butyl ether }\end{array}$ & $\begin{array}{l}846 \\
852\end{array}$ \\
\hline
\end{tabular}

component. These assumptions will be discussed in detail in the next section.

Amines have been used as the bracketing bases as far as possible to avoid further complications owing to a change of the atom at the basic center of the reference base. Exceptions are the least basic primary benzamides 12-15, which were clustered with aliphatic ethers. A disadvantage of bracketing is the limited accuracy of the PA determination. By a careful choice of the reference bases it is possible to bracket the PAs of the amides within less than $5 \mathrm{~kJ} / \mathrm{mol}$ in most cases, but the true value may be anywhere in this range. Furthermore, the PAs of the reference bases are known only to about $\pm 4 \mathrm{~kJ} / \mathrm{mol}[8]$, which expands the error bars of the PAs determined by bracketing to about \pm 8 $\mathrm{kJ} / \mathrm{mol}$. It is not possible to reduce this error by an increased number of determinations, and the main contribution comes from the error of the PAs of the reference bases used [8]. The PAs of the benzamides given in Tables 1 and 2 are the mean between the PAs of the two bracketing reference bases shown, and the maximum uncertainty is given by adding $\pm 4 \mathrm{~kJ} / \mathrm{mol}$ to the PA difference of the respective bases. The disadvantage of dismissing the interpolation method is clearly seen in the difficulty to distinguish between the groups of primary benzamides 11-14 and of tertiary benzamides 23-26 substituted by $\mathrm{Cl}$ and $\mathrm{F}$ in the meta and para positions, respectively. In these series the PA differences are obviously small, and all the amides are bracketed by 4-chloroaniline and aniline $(\triangle P A=3$ $\mathrm{kJ} / \mathrm{mol}$ ) or $N$-ethyl aniline- $m$-phenylene diamine $(\Delta \mathrm{PA}=2.5 \mathrm{~kJ} / \mathrm{mol}[8])$ and 2-butyl amine-pyridine $(\triangle P A=2 \mathrm{~kJ} / \mathrm{mol}[8])$. There are two more groups of amides $(2,4,6$, and 7 , and 16, 19, and 21) bracketed by the same pair of reference bases. To establish the order of PAs for these benzamides the dissociation of metastable proton-bound heterodimers of pairs of amides within each group was studied. These experiments resulted in the order of PAs given in Figure 1.

The PAs of the benzamides and $N, N$-dimethyl benzamides are influenced by substitution at the phenyl ring as expected; the electron-withdrawing sub- 
Table 2. Proton affinities (PA) of substituted $N, N$-dimethyl benzamides and of reference bases [ 8 ] used for bracketing

\begin{tabular}{|c|c|c|c|}
\hline Substituent & $\begin{array}{c}\text { PA } \\
(\mathrm{kJ} / \mathrm{mol})\end{array}$ & Bracketing bases & $\begin{array}{c}\text { PA } \\
(k J / m o l)\end{array}$ \\
\hline $\begin{array}{l}H \\
16\end{array}$ & $929 \pm 6$ & $\begin{array}{l}N \text {-Ethyl aniline } \\
m \text {-Phenylene diamine }\end{array}$ & $\begin{array}{c}928 \\
930.5\end{array}$ \\
\hline $\begin{array}{l}m-\mathrm{NH}_{2} \\
17\end{array}$ & $940 \pm 6$ & $\begin{array}{l}\text { 3-Methyl pyridine } \\
\text { 4-Methyl pyridine }\end{array}$ & $\begin{array}{l}938 \\
942\end{array}$ \\
\hline $\begin{array}{l}\rho-\mathrm{NH}_{2} \\
18\end{array}$ & $949 \pm 6$ & $\begin{array}{l}\text { Piperidine } \\
\text { 2,4-Dimethyl pyridine }\end{array}$ & $\begin{array}{l}947 \\
951\end{array}$ \\
\hline $\begin{array}{l}\mathrm{m}-\mathrm{OCH}_{3} \\
19\end{array}$ & $929 \pm 6$ & $\begin{array}{l}N \text {-Ethyl aniline } \\
m \text {-Phenylene diamine }\end{array}$ & $\begin{array}{c}928 \\
930.5\end{array}$ \\
\hline $\begin{array}{l}p-\mathrm{OCH}_{3} \\
20\end{array}$ & $943 \pm 6$ & $\begin{array}{l}\text { 4-Methyl pyridine } \\
\text { Diethyl amine }\end{array}$ & $\begin{array}{l}942 \\
945\end{array}$ \\
\hline $\begin{array}{l}m-\mathrm{CH}_{3} \\
21\end{array}$ & $929 \pm 6$ & $\begin{array}{l}N \text {-Ethyl aniline } \\
m \text {-Phenylene diamine }\end{array}$ & $\begin{array}{c}928 \\
930.5\end{array}$ \\
\hline $\begin{array}{l}o-\mathrm{CH}_{3} \\
22\end{array}$ & $929 \pm 6$ & $\begin{array}{l}N \text {-Ethyl anïline } \\
m \text {-Phenylene diamine }\end{array}$ & $\begin{array}{c}928 \\
930,5\end{array}$ \\
\hline $\begin{array}{l}m-F \\
23\end{array}$ & $923 \pm 5$ & $\begin{array}{l}\text { sec-Butyl amine } \\
\text { Pyridine }\end{array}$ & $\begin{array}{l}922 \\
924\end{array}$ \\
\hline $\begin{array}{l}p-F \\
24\end{array}$ & $923 \pm 5$ & $\begin{array}{l}\text { sec-Butyl amine } \\
\text { Pyridine }\end{array}$ & $\begin{array}{l}922 \\
924\end{array}$ \\
\hline $\begin{array}{l}m-C l \\
25\end{array}$ & $923 \pm 5$ & $\begin{array}{l}\text { sec-Butyl amine } \\
\text { Pyridine }\end{array}$ & $\begin{array}{l}922 \\
924\end{array}$ \\
\hline $\begin{array}{l}\rho-\mathrm{Cl} \\
26\end{array}$ & $923 \pm 5$ & $\begin{array}{l}\text { sec-Butyl amine } \\
\text { Pyridine }\end{array}$ & $\begin{array}{l}922 \\
924\end{array}$ \\
\hline $\begin{array}{l}m-C_{3} \\
27 \\
\end{array}$ & $902 \pm 9$ & $\begin{array}{l}\text { 2-Bromopyridine } \\
\text { Benzyl amine }\end{array}$ & $\begin{array}{l}898 \\
907 \\
\end{array}$ \\
\hline $\begin{array}{l}p-\mathrm{CF}_{3} \\
28 \\
\end{array}$ & $901 \pm 7$ & $\begin{array}{l}\text { 2-Bromopyridine } \\
\text { p-Phenylene diamine }\end{array}$ & $\begin{array}{l}898 \\
903 \\
\end{array}$ \\
\hline $\begin{array}{l}m-\mathrm{NO}_{2} \\
29\end{array}$ & $897 \pm 5$ & $\begin{array}{l}\text { 2-Aminophenol } \\
\text { 2-Bromopyridine }\end{array}$ & $\begin{array}{l}896 \\
898\end{array}$ \\
\hline $\begin{array}{l}p-\mathrm{NO}_{2} \\
30\end{array}$ & $897 \pm 5$ & $\begin{array}{l}\text { 2-Aminophenol } \\
\text { 2-Bramopyridine }\end{array}$ & $\begin{array}{l}896 \\
898\end{array}$ \\
\hline
\end{tabular}

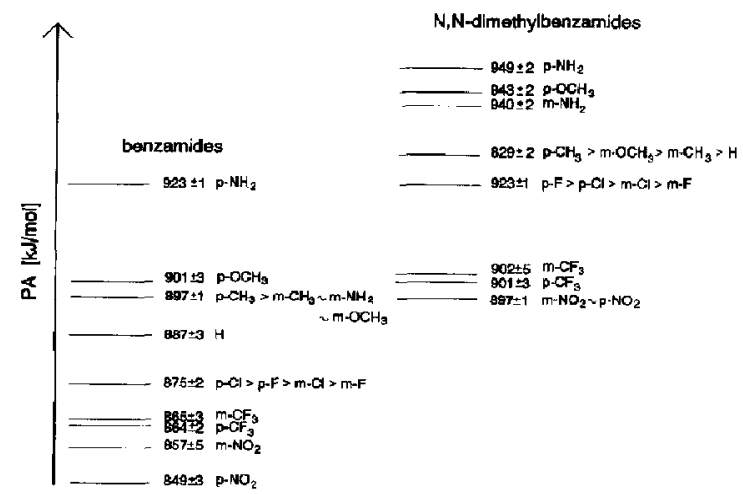

Figure 1. Order of PAs of substituted benzamides and $N, N$-dimethyl benzamides. stituents $-\mathrm{NO}_{2}$ and $-\mathrm{CF}_{3}$, which lower the $\mathrm{PA}$, and the electron-donating substituents $-\mathrm{NH}_{2}$ and $-\mathrm{OCH}_{3}$, which increase the PA (Figure 2). Similar substituent effects were observed for the $\mathrm{p} K_{n}$ of parasubstituted benzamides in aqueous solution [9]. A correlation of the substituent effects on the PAs of the benzamides with $\sigma$ constants shows much scattering (Figure 2), however, that becomes worse if $\sigma^{+}$is used. Nevertheless, the observed substituent effects permit two conclusions. First, the effects of the strongly $\pi$ donating substituents $-\mathrm{NH}_{2}$ and $-\mathrm{OCH}_{3}$ depend clearly on the position at the ring and are much stronger for para substitution both for primary benzamides and tertiary $N, N$-dimethyl benzamides. This proves unequivocally the protonation of these amides at the $\mathrm{O}$ atom of the amide group even in the case of the tertiary amides. However, the electron-withdrawing substituents $-\mathrm{CF}_{3}$ and $-\mathrm{NO}_{2}$ exhibit only small positional effects, very likely by an interruption of the unfavorable resonance interaction by a rotation of the protonated amide group out of the plane of the ben- 

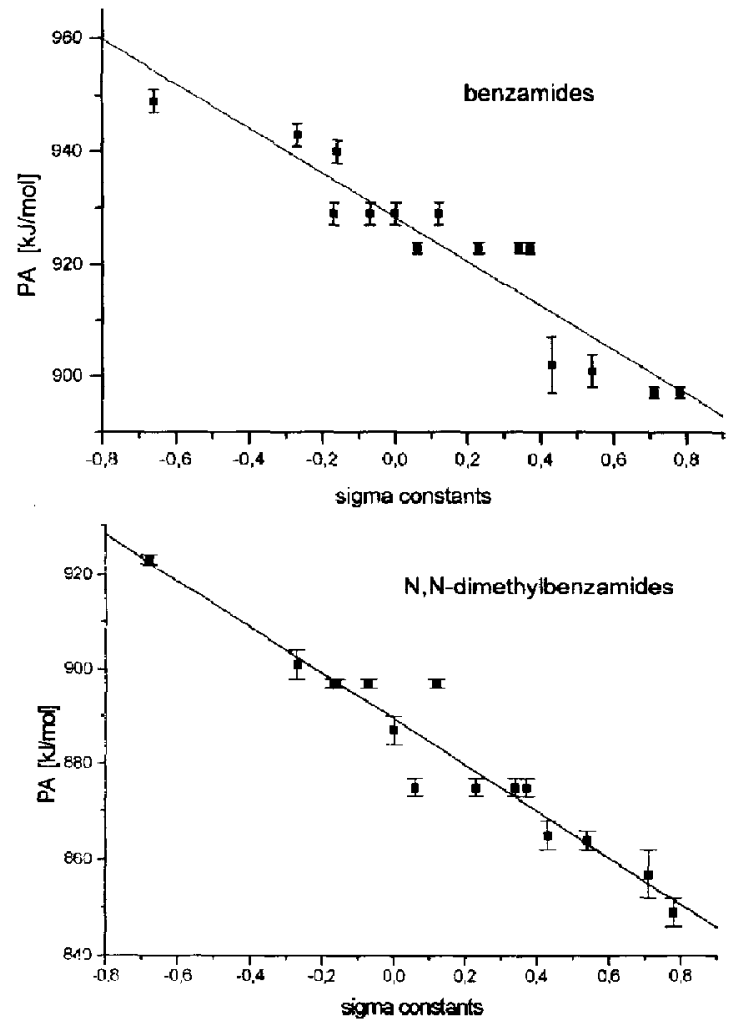

Figure 2. PAs of benzamides 1-15 and $N, N$-dimethyl benzamides $16-30$ versus Hammett $\sigma$ constants.

zene ring. In this conformation the effect of electronwithdrawing substituents depends very little on a meta or para position.

Second, the susceptibility of the PAs of the benzamides to polar substituent effect is rather small. The difference of PA between p-amino benzamide 3 and $p$-nifro benzamide 15 corresponds to $74 \mathrm{~kJ} / \mathrm{mol}$ and decreases for the $N, N$-dimethyl benzamides 18 and 30 to $52 \mathrm{~kJ} / \mathrm{mol}$ only. In contrast, the PAs of $p$-amino acetophenone and $p$-nitro acetophenone differ by 85 $\mathrm{kJ} / \mathrm{mol}$. This indicates a weak resonance interaction between the protonated amide group and the aromatic ring especially for tertiary amides. A plausible explanation is a strong resonance stabilization within the O-protonated amide group with the positive charge mostly localized at the amide- $N$ atom and not at the central amide-C atom. This effect is expected to be enhanced by $\mathrm{N}$-alkylation of the benzamide as experimentally observed. Note that the small range of PA values of substituted tertiary amides mimics an amide-N protonation [12]. A "resonance saturation" within an $\mathrm{O}$-protonated amide group was considered earlier to explain the identical substituent effects on the $p K_{a}$ of 4-substituted benzamides and 2,6-dimethyl benzamides in aqueous solution [9]. However, a diminution of a resonance interaction between the aro- matic ring and protonated amide group by delocalization of the charge into the solvate shell could not be excluded. As will be discussed elsewhere [17], the substituent effects on the PAs of 2,6-dimethyl benzamides and benzanilides are also small and follow the pattern discussed in this paper. Clearly, the unusually small susceptibility of amides toward polar substituent is an intrinsic property and is not due to solvent effects.

\section{Dissociation of Proton-Bound Heterodimers of Benzamides}

The intensity ratio of the peaks of the protonated amide and the protonated reference base in the CA spectrum of the respective proton-bound heterodimer depends on the pressure of the collision gas in the CA cell during the measurement. This effect already was observed for the dissociation of the proton-bound dimers of some peptides and polyamines [14]. For the protonated amide clusters, an example is shown in Figure 3 for the collision-induced decomposition (CID) of the proton-bound cluster of $m$-methoxy benzamide and 2-amino phenol. Unexpectedly, by increasing the pressure in the CA cell the ratio of the abundances of the protonated amide and the protonated 2-amino phenol not only approaches unity but decreases further with an increase of the pressure, that is, at large pressures of the collision gas $\mathrm{He}$ in the cell the proton stays preferentially with the less basic component of the cluster. Clearly this must be a kinetic effect of the dissociation of the proton-bound heterodimer, and the dissociation is no longer governed by the thermochemistry of the process. Although a dependence of the relative abundances for protonated amide and protonated reference base in the CA spectra is observed in all cases studied, an inversion of the ratio measured in the MIKE spectrum is observed only for those heterodimers marked in Table 3 .

The "kinetic method" for PA determination from a dissociation of the respective proton-bound cluster $\left[A \cdot H^{+} \cdot B\right.$ B] of a compound $A$ and a reference $B$ is based on eqs $1-3$ [13]:

$$
\begin{gathered}
\ln \left[\mathrm{AH}^{+}\right] /\left[\mathrm{BH}^{+}\right]=\ln k_{\mathrm{AH}+} / k_{\mathrm{BH}+}=\Delta \mathrm{PA} / R T \\
k_{\mathrm{diss}}=\mathrm{RT} / h \times \mathrm{Q}^{*} / \mathrm{Q} \times \exp \left(-\varepsilon^{0} / \mathrm{RT}\right) \\
k_{\mathrm{AH}+} / k_{\mathrm{BH}+}=\mathrm{Q}_{\mathrm{AH}+}^{*} / \mathrm{Q}_{\mathrm{BH}+}^{*} \times \exp \left(\Delta \varepsilon^{0} / R T\right) \\
\begin{aligned}
\ln \left(k_{\mathrm{AH}+} / k_{\mathrm{BH}+}\right) & =\ln \left(\nu_{\mathrm{AH}+} / \nu_{\mathrm{BH}+}\right) \times \Delta \varepsilon^{0} / R T \\
& =\ln \left(\left[\mathrm{AH}^{+}\right] /\left[\mathrm{BH}^{+}\right]\right)
\end{aligned}
\end{gathered}
$$

Equation 1 is derived from an application of the absolute rate theory to the unimolecular dissociation of the protonated cluster, which yields eq 2 , where $\varepsilon^{0}$ is the activation energy of the dissociation and $Q$ and $Q^{*}$ are the partition functions of the reactant cluster and the transition state, respectively. In the case of an activated species that decomposes via two competing reaction channels with the respective rate constants $k_{\mathrm{AH}+}$ and $k_{\mathrm{BH}+,}$ the relative rates are given by eqs 3 


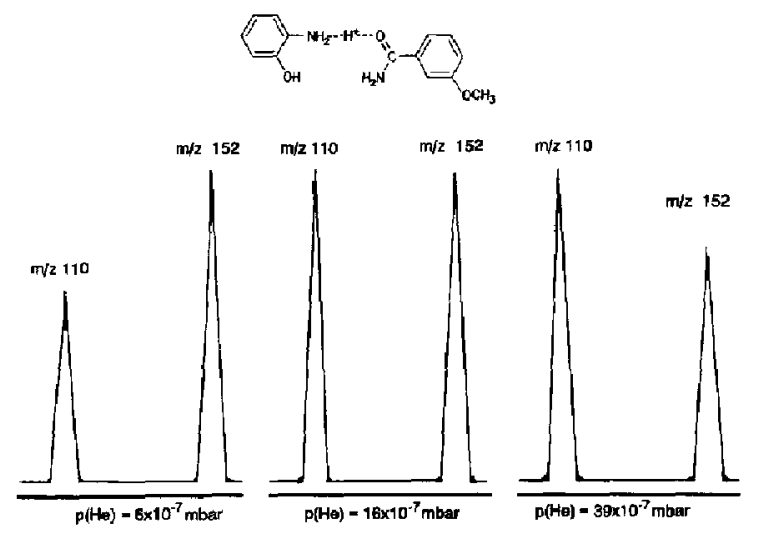

Figure 3. Partial CA mass spectra of the proton-bound heterodimer [2-aminophenol $\cdots \mathrm{H}^{+} . . m$-methoxybenzamide] at different collision gas pressures.

and $3 a$, where $\Delta \varepsilon^{0}$ is the difference of the activation energies of the two competing processes. In the case of proton-bound dimers that dissociate by cleavage of the hydrogen bond, there is very likely no extra activation barrier [4] so that $\Delta \varepsilon^{0}$ can be replaced by $\Delta P A$ to a reasonable approximation. Additionally, it is assumed that all terms of the partition functions $\left(Q_{\mathrm{AH}+}\right)^{*}$ and $\left(Q_{\mathrm{BH}+}\right)^{*}$ cancel with the exception of the vibrational terms $\nu_{\mathrm{AH}+}$ and $\nu_{\mathrm{BH}+}$ of the hydrogen bond in (A .. $H^{+}$. B) [13]. Furthermore, by a proper choice of $A$ and $B$ that both expose identical atoms at their basic center to the proton the ratio $\nu_{\mathrm{AH}+} / \nu_{\mathrm{BH}+}$ is close to 1 , so eventually eq 1 is obtained. In addition to the special assumptions made during the generation of eq 1, the critical term is the effective temperature $T$ of the protonated dimer that is not in thermal equilibrium with its environment. In fact, $T$ is usually determined by a calibration experiment, but it is not guaranteed that it will remain constant throughout a series of measurements. Furthermore, because $T$ is the effective temperature of the species activated for the dissociation, $T$ must depend on the details of the activation process during CID.

If the dissociation of the isolated proton-bound heterodimer $\left(\mathrm{A} \cdot \mathrm{H}^{+} \cdot \cdot \mathrm{B}\right)$ is treated by the formalism of the quasi-equilibrium theory (QET) [18], a different set of eqs $4-6$ is obtained:

$$
\begin{gathered}
k_{\mathrm{diss}}(E)=\frac{1}{h} \times \frac{W^{*}\left(E-\varepsilon^{0}\right)}{\rho(E)} \\
k_{\mathrm{diss}}(E)=\frac{\prod_{i}^{N} h \nu_{i}}{\prod_{i}^{N-1} h \nu_{i}^{*}} \times \frac{\left(E-\varepsilon^{0}\right)^{N-1}}{E^{N-1}} \\
\frac{k_{\mathrm{AH}+}}{k_{\mathrm{BH}+}}(E)=\frac{\prod_{i(\mathrm{BH}+)}^{N-1} h \nu_{i(\mathrm{BH}+)}^{*}}{\prod_{i(\mathrm{AH}+)}^{N-1} h \nu_{i(\mathrm{AH}+)}^{*}} \times \frac{\left(E-\varepsilon_{\mathrm{AH}+}^{0}\right)^{N-1}}{\left(E-\varepsilon_{\mathrm{BH}+}^{0}\right)^{N-1}} \\
\frac{k_{\mathrm{AH}+}}{k_{\mathrm{BH}+}}(E)=\frac{\nu_{\mathrm{BH}+}}{\nu_{\mathrm{AH}+}} \times \frac{\left(E-\varepsilon_{\mathrm{AH}+}^{0}\right)^{N-1}}{\left(E-\varepsilon_{\mathrm{BH}+}^{0}\right)^{N-1}}=\frac{\left[\mathrm{AH}^{+}\right]}{\left[\mathrm{BH}^{+}\right]}
\end{gathered}
$$

Equation 5 arises from the basic equation (eq 4) by the representation of the ion and the activated complex of the dissociation by a collection of $N$ and $(N-1)$ weakly coupled harmonic oscillators, respectively. In the case of two reactions that compete for the decomposition of the same ion, the ratio of the respective rate constants $k_{\mathrm{AH}+} / k_{\mathrm{BH}+}$ is given by eq 6 , which reduces to eq $6 a$ under the assumption used before [in eq (3a)] that all terms of the partition function cancel with exception of $\nu_{\mathrm{AH}+}$ and $\nu_{\mathrm{BH}+}$. However, it is obvious from eq $6 \mathrm{a}$ that the ratio $k_{\mathrm{AH}+} / k_{\mathrm{BH}+}$ and the relative abundances of the product ions $\mathrm{AH}^{+}$and $\mathrm{BH}^{+}$depend on the internal energy $E$ of the proton-bound dimer as well as on the activation energies $\varepsilon_{\mathrm{AH}+}^{0}$ and $\varepsilon_{\mathrm{BH}+}^{0}$ of the competing dissociations. Protonated clusters of low internal energy $\left(\varepsilon_{\mathrm{AH}+}^{0}<E<\varepsilon_{\mathrm{BH}+}^{0}\right)$ dissociate only by generation of $\mathrm{AH}^{+}$. With increasing $E$, product ions $\mathrm{BH}^{+}$are also formed in competition, and in the limiting case of a very large $E$, the ratio $k_{\mathrm{AH}+} / k_{\mathrm{BH}+}$ and the intensity ratio $\left[\mathrm{AH}^{+}\right] /\left[\mathrm{BH}^{+}\right]$correspond to $\nu_{\mathrm{AH}+} / \nu_{\mathrm{BH}+}$, which is taken to be 1 in the kinetic method.

From QET it is easy to understand that $\left[\mathrm{AH}^{+}\right] /\left[\mathrm{BH}^{+}\right]$during $\mathrm{CID}$ of protonated heterodimers depends on the pressure within the collision cell because the mean internal energy of an ensemble of colliding ions increases with the probability of multiple collisions [19]. Furthermore, it is clear that the kinetic method for PA determination can be taken only as a bracketing method and that the observed internal energy of the dissociating protonated clusters should be as low as possible. However, it is not obvious why, in some cases, the ratio $\left[\mathrm{AH}^{+}\right] /\left[\mathrm{BH}^{+}\right]$inverts to values below 1 with increasing internal energy.

The simplest explanation of this effect is that $\nu_{\mathrm{AH}+} / \nu_{\mathrm{BH}+}$ deviates from 1 . This would be the case if the strength of the hydrogen bonds to $A$ and $B$ in the cluster $\left(A \cdot \cdot \mathrm{H}^{+} \cdot \mathrm{B}\right)$ differ considerably because of different atoms at the basic centers of $A$ and $B$. In the proton-bound clusters studied here, one component (A) is always a benzamide whereas the second component (B) is mostly an amine or a pyridine. Thus, the hydrogen bonds in $\mathrm{AH}^{+}$and $\mathrm{BH}^{+}$are different: they extend to the $\mathrm{O}$ atom of the amide, but to the $\mathrm{N}$ atom of the reference base. The difference should be almost identical in all clusters studied by CID, however, and it is difficult to explain by this effect alone why an inversion of the intensity ratio $\left[\mathrm{AH}^{+}\right] /\left[\mathrm{BH}^{+}\right]$with increasing collision gas pressure is observed only in certain cases. The deviations from the ideal behavior of protonated clusters according to the kinetic method have been attributed to conformational changes of the bases during dissociation of the proton-bound heterodimer. It is unlikely that this is also the cause for the effect of CID gas pressure on the intensity variation in the CA spectra of the proton-bound heterodimers of amides observed here.

An inspection of Table 3 reveals that the intensity inversion is observed if the reference base $B$ is the 
slightly less basic component in the proton-bound heterodimer, and that the effect is more often observed for tertiary $N, N$-dimethyl benzamides than for primary benzamides. We suggest that the effect of an increasing excess internal energy of the proton-bound heterodimer (caused by the increasing collision gas pressure) on the branching ratio of the dissociation is a consequence of an asymmetric double-well potential energy hypersurface for the proton-bound heterodimer. This asymmetric double well arises from a strong electrostatic interaction of the polar amide group with cations. A strong interaction of this type is also the reason for the well known solubility of many salts in $N, N$-dimethyl formamide (DMF) and other liquid amides. In the gas phase this strong ion-dipole interaction specifically favors a complex of a positive ion and a neutral amide molecule.

Usually it is assumed that the complementary complexes of proton-bound dimers and heterodimers that correspond to the two possible asymmetric hydrogen bonds are separated by no energy barrier or only a small energy barrier without any effect on the rates of

Table 3. Reversal of the intensity ratio $\left[\mathrm{AH}^{+}\right] /\left[\mathrm{BH}^{+}\right]$with increasing collision gas pressure in the CA mass spectra of proton-bound heterodimers of benzamide $A$ and reference base $B$




Table 3. (continued)

\begin{tabular}{|c|c|c|c|c|}
\hline Substituent & PA & Reference base & PA & Inversion \\
\hline $\begin{array}{l}m-\mathrm{NO}_{2} \\
14\end{array}$ & 857 & $\begin{array}{l}\text { Di-n-butyl ether } \\
\text { Diisopropyl ether }\end{array}$ & $\begin{array}{l}852 \\
862\end{array}$ & $\begin{array}{c}\text { no } \\
\text { yes }^{\theta}\end{array}$ \\
\hline $\begin{array}{l}p-\mathrm{NO}_{2} \\
15\end{array}$ & 849 & $\begin{array}{l}\text { Di-n-propyl ether } \\
\text { Di-n-butyl ether }\end{array}$ & $\begin{array}{l}846 \\
852\end{array}$ & $\begin{array}{l}\text { no } \\
\text { no }\end{array}$ \\
\hline \multicolumn{5}{|c|}{$N . N$-Dimethyl benzamides } \\
\hline $\begin{array}{l}\mathrm{H} \\
16\end{array}$ & 929 & $\begin{array}{l}\text { Pyridine } \\
N \text {-Ethyl aniline } \\
m \text {-Phenylene diamine } \\
N, N \text {-Dimethyl aniline }\end{array}$ & $\begin{array}{c}924 \\
928 \\
930.5 \\
935\end{array}$ & $\begin{array}{l}\text { yes } \\
\text { no } \\
\text { no } \\
\text { no }\end{array}$ \\
\hline $\begin{array}{l}m-\mathrm{NH}_{2} \\
17\end{array}$ & 940 & $\begin{array}{l}\text { 3-Methyl pyridine } \\
\text { 4-Methyl pyridine } \\
\text { Diethyl a mine }\end{array}$ & $\begin{array}{l}938 \\
942 \\
945\end{array}$ & $\begin{array}{c}\text { yes } \\
\text { no } \\
\text { no }\end{array}$ \\
\hline $\begin{array}{l}\rho-\mathrm{NH}_{2} \\
18\end{array}$ & 949 & $\begin{array}{l}\text { 4-Methyl pyridine } \\
\text { Diethyl amine } \\
\text { Piperidine } \\
\text { 2,4-Dimethyl pyridine }\end{array}$ & $\begin{array}{l}942 \\
945 \\
947 \\
951\end{array}$ & $\begin{array}{l}\text { yes } \\
\text { yes } \\
\text { yes } \\
\text { no }\end{array}$ \\
\hline $\begin{array}{l}m-\mathrm{OCH}_{3} \\
19\end{array}$ & 929 & $\begin{array}{l}N \text {-Ethyl aniline } \\
m \text {-Phenylene diamine } \\
N, N \text {-Dimethyl aniline }\end{array}$ & $\begin{array}{c}928 \\
930.5 \\
935\end{array}$ & $\begin{array}{l}\text { no } \\
\text { no } \\
\text { no }\end{array}$ \\
\hline $\begin{array}{l}\rho-\mathrm{OCH}_{3} \\
20\end{array}$ & 943 & $\begin{array}{l}\text { N-Ethyl aniline } \\
\text { m-Phenylene diamine } \\
\text { 3-Methyl pyridine } \\
\text { 4-Methyl pyridine } \\
\text { Diethyl amine }\end{array}$ & $\begin{array}{c}928 \\
930.5 \\
938 \\
942 \\
945\end{array}$ & $\begin{array}{c}\text { no } \\
\text { yes } \\
\text { yes } \\
\text { yes } \\
\text { no }\end{array}$ \\
\hline $\begin{array}{l}m-\mathrm{CH}_{3} \\
21\end{array}$ & 929 & $\begin{array}{l}N \text {-Ethyl aniline } \\
m \text {-Phenylene diamine } \\
N, N \text {-Dimethyl aniline }\end{array}$ & $\begin{array}{c}928 \\
930.5 \\
935\end{array}$ & $\begin{array}{l}\text { no } \\
\text { no } \\
\text { no }\end{array}$ \\
\hline $\begin{array}{l}p-\mathrm{CH}_{3} \\
22\end{array}$ & 929 & $\begin{array}{l}N \text {-Ethyl aniline } \\
m \text {-Phenylene diamine }\end{array}$ & $\begin{array}{c}\mathbf{9 2 8} \\
\mathbf{9 3 0 . 5}\end{array}$ & $\begin{array}{l}\text { ves } \\
\text { no }\end{array}$ \\
\hline $\begin{array}{l}m-F \\
23\end{array}$ & 923 & $\begin{array}{l}\text { sec-Butyl amine } \\
\text { Pyridine }\end{array}$ & $\begin{array}{l}922 \\
924\end{array}$ & $\begin{array}{l}\text { yes } \\
\text { no }\end{array}$ \\
\hline $\begin{array}{l}\rho-\mathrm{F} \\
24\end{array}$ & 923 & $\begin{array}{l}\text { sec-Butyl amine } \\
\text { Pyridine }\end{array}$ & $\begin{array}{l}922 \\
924\end{array}$ & $\begin{array}{l}\text { yes } \\
\text { no }\end{array}$ \\
\hline $\begin{array}{l}m-\mathrm{Cl} \\
25\end{array}$ & 923 & $\begin{array}{l}\text { Benzyl amine } \\
\text { N-Methyl aniline } \\
\text { sec-Butyl amine } \\
\text { Pyridine }\end{array}$ & $\begin{array}{l}907 \\
912.5 \\
922 \\
924\end{array}$ & $\begin{array}{c}\text { no } \\
\text { yes } \\
\text { yes }^{a} \\
\text { no }\end{array}$ \\
\hline $\begin{array}{l}\rho-\mathrm{Cl} \\
26\end{array}$ & 923 & $\begin{array}{l}\text { sec-Butyl amine } \\
\text { Pyridine } \\
\text { N-Ethyl e niline }\end{array}$ & $\begin{array}{l}922 \\
924 \\
928\end{array}$ & $\begin{array}{c}\text { yes }^{a} \\
\text { no } \\
\text { no }\end{array}$ \\
\hline $\begin{array}{l}m-C F_{3} \\
27\end{array}$ & 902 & $\begin{array}{l}\text { 2-Bromopyridine } \\
\text { Benzyl amine }\end{array}$ & $\begin{array}{l}898 \\
907\end{array}$ & $\begin{array}{l}\text { yes } \\
\text { no }\end{array}$ \\
\hline $\begin{array}{l}\rho-\mathrm{CF}_{3} \\
28\end{array}$ & 901 & $\begin{array}{l}\text { 2-Bromopyridine } \\
\text { p-Phenylene diamine }\end{array}$ & $\begin{array}{l}898 \\
903\end{array}$ & no \\
\hline $\begin{array}{l}m-\mathrm{NO}_{2} \\
29\end{array}$ & 897 & $\begin{array}{l}\text { 2-Aminophenol } \\
\text { 2-Bromopyridine }\end{array}$ & $\begin{array}{l}896 \\
898\end{array}$ & $\begin{array}{l}\text { yes } \\
\text { no }\end{array}$ \\
\hline $\begin{array}{l}p-\mathrm{NO}_{2} \\
30\end{array}$ & 897 & $\begin{array}{l}\text { 2-Aminophenal } \\
\text { 2-Eramopyridine }\end{array}$ & $\begin{array}{l}896 \\
898\end{array}$ & $\begin{array}{l}\text { yes } \\
\text { no }\end{array}$ \\
\hline
\end{tabular}

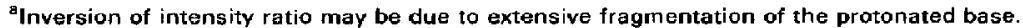




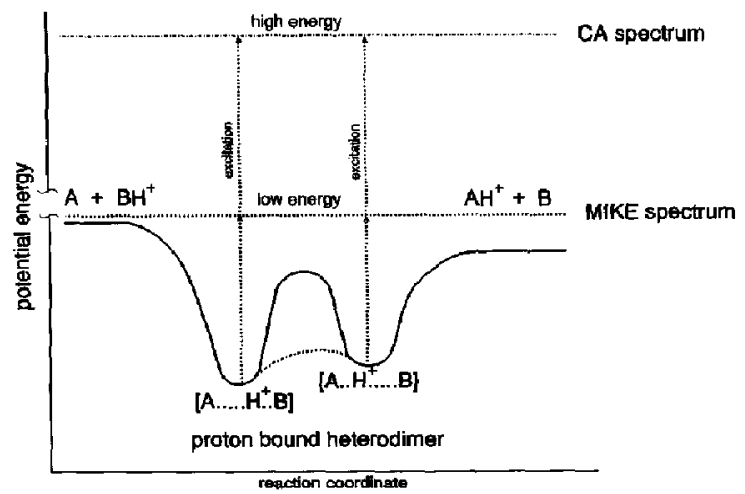

Figure 4. Schematic potential energy diagram for a protonbound amide heterodimer.

the dissociation [4]. This model was developed by theoretical calculations and experimental studies of simple proton-bound clusters [20]. The situation is very likely more complex in the case of proton heterodimers composed of large polar molecules because the relative orientation of the two components for optimal hydrogen bond strength may be hampered sterically. It is known that the activation energy of proton transfer depends critically on the correct alignment of the donor and acceptor groups [20] in the complex. Furthermore, the potential energy of the complex is determined not only by the energy gain of the hydrogen bond, but also by electrostatic interaction between ionic and neutral species. The amide group has a very large dipole moment, and the energy gained by ion-dipole interaction between a cation and a neutral amide molecule is rather large. Thus, if the second component $B$ is not very polar and has a PA only a few kilojoules per mole less than the amide $A$, the asymmetric complex $\left(\mathrm{BH}^{+} . . \mathrm{A}\right)$ with the proton attached to the less basic component may be energetically favored over the complementary complex $\left(B \cdot \mathrm{H}^{+} \mathrm{A}\right)$ (Figure 4).

This unique structure of the potential energy hypersurface has few consequences for the dissociation of proton-bound heterodimers of low internal energies $E$. Either the formation of the protonated amide $\mathrm{AH}^{+}$is the only reaction possible $\left(\varepsilon_{\mathrm{AH}+}^{0}<E<\varepsilon_{\mathrm{BH}+}^{0}\right)$ or the dissociation rates are slow compared to the rate of interconversion of the two asymmetric complexes. In this case the dissociation is dominated by a reaction via the energetically most favored exit channel [21]. However, this may change at large excess energies of the proton-bound dimer because the dissociation rates are now much faster and may exceed the rate of isomerization. In this case the population of the ground-state configuration of the proton-bound heterodimer becomes important, and because more ground-state complexes have the proton attached to the less basic component $\mathrm{B}$, dissociation into $\mathrm{BH}^{+}$ becomes favored.
This model for the dissociation of the proton-bound amide heterodimers requires a rather slow interconversion of the two asymmetric complexes. The reason for this is not necessarily a potential energy barrier between the two species. A proton bridge demands a special orientation of the components that may be different for the complexes $\left(\mathrm{BH}^{+} \cdot . \mathrm{A}\right)$ and $\left(\mathrm{B} \cdot \cdot \mathrm{H}^{+} \mathrm{A}\right)$. In this case the proton jump between $A$ and $B$ is accompanied by considerable reorientation within the cluster. Activation barriers owing to reorientation effects (entropic effects) are well known for reactions in solution, and such entropy effects also have been discussed for proton transfer reactions in the gas phase [22]. Theoretical calculations have shown [20] that the dynamics of proton transfer depend strongly on the chemical surroundings of the transferred proton. It may be significant that the intensity reversal of $\left[\mathrm{AH}^{+}\right]$ and $\left[\mathrm{BH}^{+}\right]$during the CID of the proton-bound amide clusters is predominantly observed for the complexes of tertiary $N, N$-dimethyl benzamides that contain only the "bridging" proton. In the proton-bound heterodimers of benzamides the additional mobile protons at the primary amino group may assist in the proton jump and the reorientation of the components. It will be of much interest for the understanding of the dynamics of proton transfer reactions and of hydrogen bonding of amides and proteins to confirm this model by further experiments of the gas-phase properties of proton-bound heterodimers by using multidentate ligands for the proton to induce reorientations in the protonated clusters during dissociation.

\section{Acknowledgment}

The financial assistance of this work by the Deutsche Forschungsgemeinschaft is gratefully acknowledged. We thank M. Asresahegn, Fakultät für Chemie der Universität Bielefeld, for technical assistance with the mass spectrometric measurements and Dr. F. Strehle for his helpful discussions.

\section{References}

1. Lowry, T. H.; Schueller Richardson, K. Mechanism and Theory in Organic Chernistry, 3rd ed.; Harper and Row: New York, 1987.

2. Aue, D. H.; Bowers, M. T. In Gas Phase Ion Chemistry, Vol. 2; Bowers, M. T., ed.; Academic Press: New York, 1979; Chap. 9.

3. Dewar, M. S. J. Enzyme 1986, 36, 8.

4. Uggerud, E. Mass Spectrom. Rev. 1992, 11, 389.

5. Pimentel, G. C.; McClellan, A. L. The Hydrogen Bortd; Freeman: San Francisco, CA, 1960.

6. Englander, S. W.; Kallenbach, N. R. Quart. Rev. Biophys. 1983, $16,521$.

7. (a) Meot-Ner (Mautner), M.; Hunter, E. P.; Field, F. H. J. Am. Chem. Soc. 1979, 101, 686; (b) Locke, M; McIver, R. I. Am. Chem. Soc. 1983, 105, 4226; (c) Bojesen, G. J. Am. Chem. Soc. 1987, 109, 5557; (d) Meot-Ner (Mautner), M. I. Am. Chem. Soc. 1988, 110, 3071; (e) Isa, K.; Omote, T.; Amaya, M. Org. Mass Spectrarn. 1990, 25, 620; (f) Wu, Z.; Fenselau, C. Rapid Commun. Mass Spectrom. 1992, 6, 403; (g) Wu, J.; Lebrilla, C. 
B. I. Am. Chem. Soc. 1993, 115, 3270; (h) Bliznyuk, A. A.; Schaefer, H. F., III; Amster, 1. J. I. Am. Chem. Soc. 1993, 115, 5149; (i) Li, X; Harrison, A. G. Org. Mass Spectrom. 1993, 28 , 366.

8. Lias, S. G.; Bartmess, J. E.; Liebman, J. F,; Holmes, J. L.; Levin, R. D.; Mallard, W. G. J. Phys. Chem. Ref. Data 1988, 17, Suppl. 1.

9. De Maris, P.; Barbieri, C. L.; Spinelli, D.; Dell'Erba, C.; Novi, M,; Petrillo, G.; Sancassan, F. J. Chem. Soc., Perkin Trans. II $1991,373$.

10. Perrin, C. L. Acc. Chem. Res. 1989, 22, 268.

11. Scheiner, S.; Wang, L. J. Am. Chem. Sac. 1993, 115, 1958.

12. Thielking, G. Dissertation, Universität Bielefeld, 1991.

13. (a) Cooks, R. G.; Krüger, T. L. I. Am. Chem. Soc. 1977, 99, 1279; (b) McLuckey, S. A.; Cameron, D.; Cooks, R. G. I. Am. Chem. Soc. 1981, 103, 1313.
14. Cheng, X.; Wu, Z; Fenselau, C. I. Am. Chem. Soc. 1993, 115, 4844 .

15. Majumdar, T. K.; Clairet, F.; Tabet, J.-C.; Cooks, R. G. I. Am. Chern. Soc. 1992, 114, 2897.

16. Heinz, G. O.; Becker, U. A. Organtkum, Organisch-chemisches Grundpraktikum, 19th ed.; Barth, Deutsches Verlag der Wissenschaften: Leipzig, 1993.

17. Grützmacher, H.-F.; Caltapanides, A.; Beugholt, C.; Quasdorf, J.-M., to be published.

18. Eyring, H.; Lin, S. H.; Lin, S. M. Basic Chemical Kinetics; Wiley: New York, 1980; Chap. 5.

19. Mcluckey, S. A. I. Am. Soc. Mass Spectrom. 1992, 3, 599.

20. Scheiner, S. Acc. Chem. Res. 1985, 18, 174.

21. Levsen, K. Fundamental Aspects of Organic Mass Spectrometry; Verlag Chemie: Weinheim, 1978.

22. Meot-Ner (Mautner), M.; Smit, S. C. I. Am. Chem. Soc. 1991, $113,862$. 